\title{
Benign Thyroid Mass Causing Necrosis of Tracheal Cartilage
}

\author{
Sung Jae Park ${ }^{1}$, Yong Soo Lee ${ }^{1}$, Seung Hoon Lee ${ }^{1}$, and Bon Seok Koo ${ }^{1,2}$ \\ ${ }^{1}$ Department of Otorhinolaryngology-Head and Neck Surgery, ${ }^{2}$ Research Institute for Medical Sciences, School of Medicine, \\ Chungnam National University, Daejeon, Korea
}

\section{기관연골괴사를 유발한 양성 갑상선 종양}

\author{
박성제 $^{1} \cdot$ 이용수 $^{1} \cdot$ 이승훈 $^{1} \cdot$ 구본석 $^{1,2}$ \\ 충남대학교 의과대학 이비인후-두경부외과학교실, ${ }^{1}$ 의학연구소 ${ }^{2}$
}

\author{
Received December 17, 2015 \\ Revised January 27, 2016 \\ Accepted February 11, 2016 \\ Address for correspondence \\ Bon Seok Koo, MD, PhD \\ Department of Otorhinolaryngology- \\ Head and Neck Surgery, \\ School of Medicine, \\ Chungnam National University, \\ 282 Munhwa-ro, Jung-gu, \\ Daejeon 35015, Korea \\ Tel $+82-42-280-7695$ \\ Fax $+82-42-253-4059$ \\ E-mail bskoo515@cnuh.co.kr
}

Thyroid tumors are usually asymptomatic, but occasionally they can cause upper airway obstruction by compressing the trachea in cases of benign mass or invading intraluminal tracheal wall in locally advanced carcinoma. There were a few case reports of rapidly enlarging benign tumors of thyroid causing upper airway distress symptoms, but there has been no case report showing necrosis of tracheal cartilage by benign thyroid mass. When the thyroid cartilage wall is actually invaded by thyroid mass, we should consider of the possibility of malignant transformation. We experienced a case of unilateral benign thyroid mass causing acute airway obstruction and necrosis of tracheal cartilage. Therefore, we present the case with a literature review. Korean J Otorhinolaryngol-Head Neck Surg 2016;59(11):792-5

\section{서 론}

갑상선 종양은 대개 무증상이나, 드물게 갑상선 종양이 기 관을 심하게 압박하거나, 갑상선 암종이 기관내로 침범하는 경우에 상기도폐쇄의 증상이 나타날 수 있다. ${ }^{1-3)}$ 양성 갑상선 종양의 경우 오랜 시간 동안 서서히 크기가 증가하므로 급성 상기도폐쇄를 일으키는 경우는 드문 것으로 알려져 있지만, 종양 내 출혈 등으로 인한 급성 상기도폐쇄의 증례들이 간혹 보고되고 있다. ${ }^{4)}$ 그러나 양성 갑상선 종양의 만성적인 기관 압박으로 인한 기관연골의 괴사성 변화에 대해서는 현재까 지 보고된 바가 없었다. 본 저자들은 최근에 양성 갑상선 종양 에 의한 기관연골의 괴사성 변화와 급성 상기도폐쇄로 수술 적 치료를 시행받은 1 예를 경험하였기에 문헌 고찰과 함께 보 고하고자 한다.

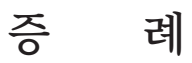

75세 여자 환자가 2개월 전부터 발생하여 서서히 악화되는 호흡곤란을 주소로 응급실로 내원하였다. 약 20년 전부터 우측 전경부의 종물이 있었으나 별다른 증상 호소는 없었다. 내원 1 개월 전 갑자기 호흡곤란이 악화되며 흥통이 발생하여 타 병원 응급실 내원하였고, 급성심근경색으로 진단받고 경피 적 관상동맥 중재술(percutaneous coronary intervention)을 시행하였으나, 시술 중 심정지 발생하여 심폐소생술을 시행 하였다. 이후 다발성 장기부전으로 1 주 동안 혈액투석 및 중 환자실 치료를 받았다. 이후에도 지속적인 흥부 불편감 및 호흡곤란을 호소하여 시행한 흥부 전산화단층촬영에서 우 측 갑상선 종물로 인한 기관내 협착 소견이 관찰되어 본원으 로 전원되었다.

내원 당시 의식은 명료하였고, 연하통 및 흥통 호소는 없었 다. 이학적 검사에서 우측 전경부 종대가 관찰되었고, 후두 내 

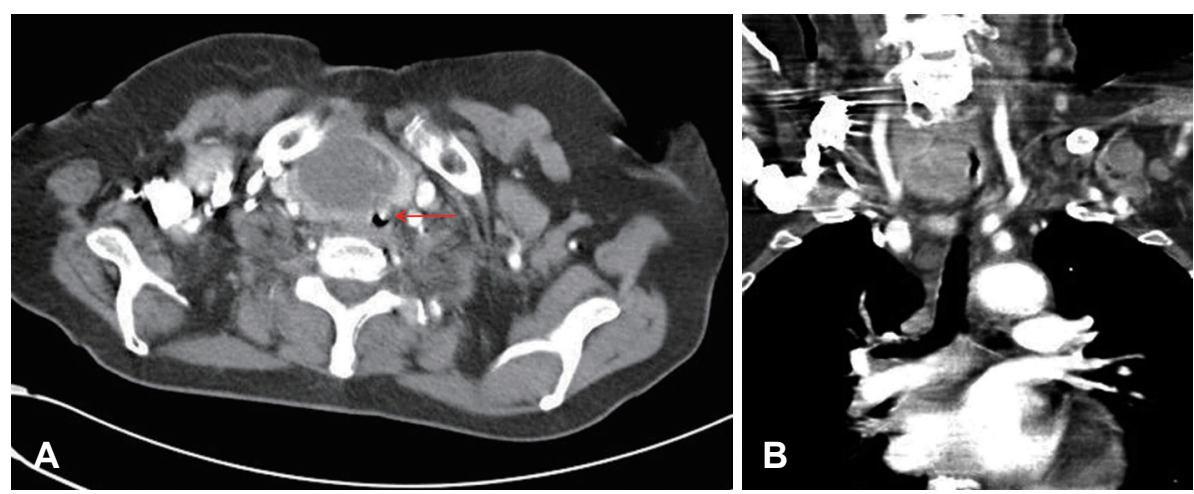

Fig. 1. Axial image of neck CT scan. There is a $6.3 \times 4.5 \mathrm{~cm}$ sized, heterogeneously enhancing mass in right thyroid gland. Invasion of tracheal wall by thyroid mass is suspicious (arrow) (A). Coronal image of neck CT scan. Thyroid mass is compressing and displacing the trachea (B).

시경에서 성대 움직임은 정상이었으나 흡기 시 천명과 함께 호 흡곤란을 호소하였다. 일반 혈액검사, 화학검사, 요검사에서 특이사항은 없었으며, 갑상선 기능 검사에서 유리 T4 0.96 ng/dL, T3 1.24 ng/mL, Anti-TPO Ab $3.41 \mathrm{U} / \mathrm{mL}$, Antithyroglobulin $\mathrm{Ab} 44.77 \mathrm{U} / \mathrm{mL}$ 였고, TSH $4.21 \mathrm{uIU} / \mathrm{mL}$ 로 정상의 갑상선 기능 상태를 보였다. 내원 당시 동맥혈액가스 분석검사는 $\mathrm{pH} 7.40, \mathrm{pCO} 237 \mathrm{~mm} \mathrm{Hg}, \mathrm{pO} 282 \mathrm{~mm} \mathrm{Hg}$, 산 소포화도 $96 \%$ 였다. 심전도 검사에서 동성빈맥을 보였으며, 심초음파 검사에서 경도의 대동맥판막 협착증 소견을 보였 으나, 좌심실기능부전 소견은 관찰되지 않았다. 단순흥부촬 영에서는 좌측 하부 구역기관지의 무기폐 소견 이외의 특이 사항은 없었다. 경부 전산화단층촬영에서 장경 $6 \mathrm{~cm}$ 의 비균 질성 조영증강의 우측 갑상선 종물이 관찰되었으며, 기관을 압박하여 기관이 좌측으로 편위되어 있었고, 기관 내강의 협 착이 $80 \%$ 이상 동반된 소견을 보였다. 또한 종물의 일부가 기 관내로 침범하는 양상의 소견이 보였으나 명확하지 않아 감 별이 필요하였다. 그 외 비정상적인 림프절 증대나 병변은 보 이지 않았다(Fig. 1). 수술 전 기관내 병변 확인을 위해 기관 지내시경을 계획하였으나, 환자의 협조가 이루어지지 않아 시 행하지 못했다. 경부 초음파 검사에서 마찬가지로 우측 갑상 선 하극의 종물을 관찰할 수 있었고, 세침흡인검사를 시행하 였으며, 양성 여포성 결절 소견을 보였다. 추가적인 침생검 (core needle biopsy)이나 자기공명영상(magnetic resonance imaging)은 시행하지 않았으며, 비독성 결절성 갑상선종(nontoxic nodular goiter) 또는 갑상선암으로의 변환 가능성을 의심하고, 수술을 계획하였다.

환자는 1 개월 전 급성심근경색으로 경피적 관상동맥 중재 술 시행 후 aspirin 복용 중이었으며, 수술 시 출혈 위험을 줄 이기 위해 수술 5일 전부터 aspirin 복용을 중단하고, 수술 4시 간 전까지 intravenous heparin을 투약하였다. 경부 전산화단 층촬영에서 관찰되었던 종물의 기관내 침범이 의심되었던 부위에서 기관 일부의 괴사 소견이 관찰되었으나 직접적인 기 관내 침범 소견은 없었다. 종물을 제거하자 $2.0 \times 1.0 \mathrm{~cm}$ 크기

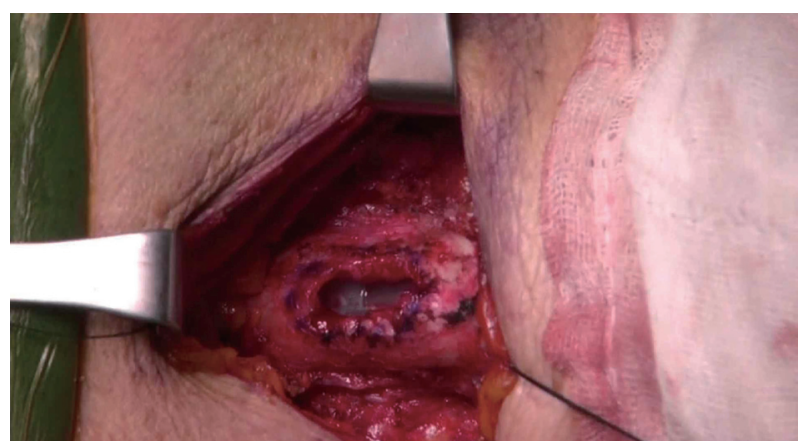

Fig. 2. Intraoperative finding of case. There is about $2.0 \times 1.0 \mathrm{~cm}$ sized tracheal wall defect with necrotic margin.

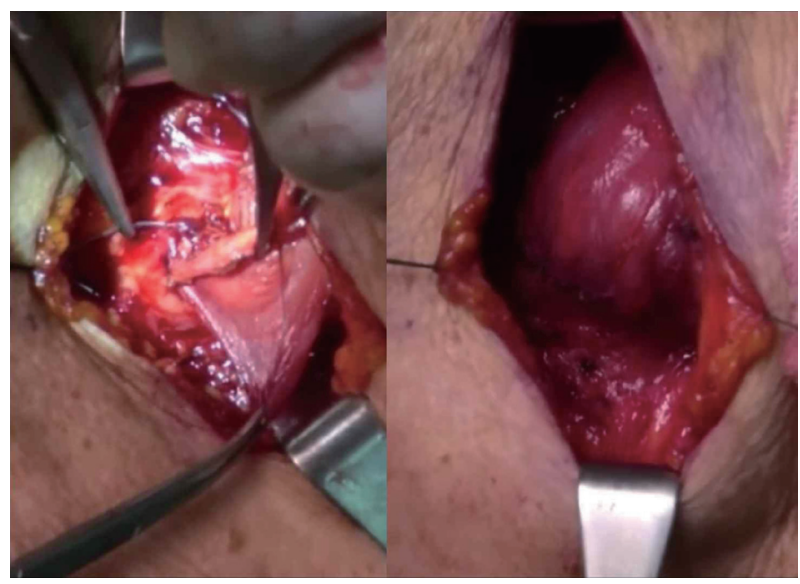

Fig. 3. Intraoperative finding of case. The sternocleidomastioid myoperiosteal flap for the reconstruction of a tracheal defect.

의 기관벽의 결손이 발생하여(Fig. 2), 우측 쇄골 골막을 포 함한 흉쇄유돌근의 근골막 피판(sternocleiodomastoid myoperiostral flap)을 이용하여 재건을 시행하였다(Fig. 3). 갑상 선 전절제술을 시행하였고, 수술 시 양측 반회후두신경의 손 상은 없었으며, 상부 부갑상선은 모두 보존되었으며, 하부 부 갑상선을 모두 확인하고 좌측 흥쇄유돌근에 이식하였다. 수 술로 제거된 우측 갑상선 종물의 내부에서 출혈성 변화가 있 음을 관찰하였다(Fig. $4 \mathrm{~A})$. 영구 절편 병리조직학적 검사에 서 우측의 갑상선 종물은 낭성 및 출혈성 변화를 동반한 결 

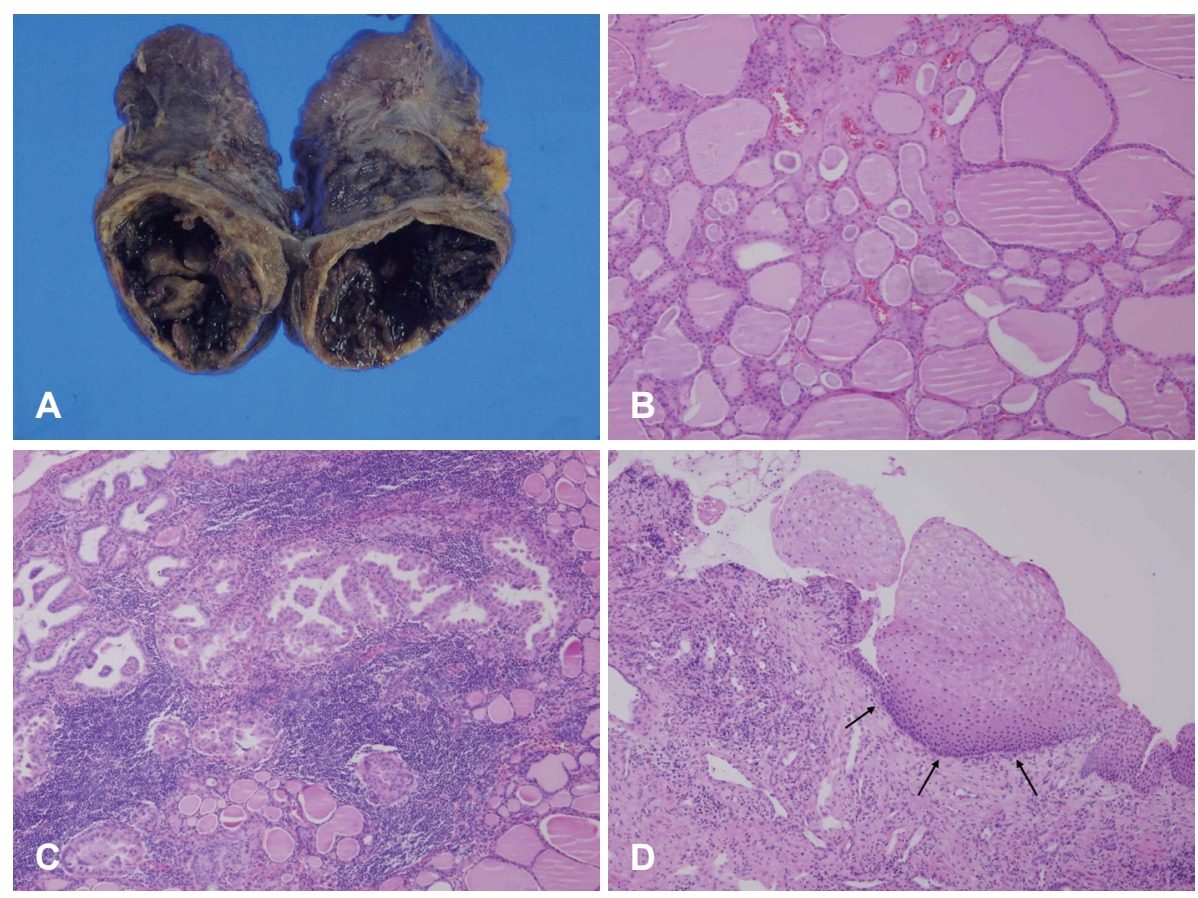

Fig. 4. Histopathologic findings. Cut section of thyroid mass shows old hemorrhage (A). Histologic section shows nodular hyperplasia with cystic change $(\mathrm{H}-\mathrm{E}, \times 40)(\mathrm{B})$. Papillary microcarcinoma, $0.1 \times 0.1 \mathrm{~cm}$ sized, was found in left lobe of thyroid $(\mathrm{H}-\mathrm{E}$, $\times 40)(C)$. Histologic section shows chronic active inflammation with granulation tissue proliferation. Leukocytes infiltration into thyroid cartilage (arrows) $(\mathrm{H}-\mathrm{E}, \times 100)(\mathrm{D})$.

절성 과증식(nodular hyperplasia)으로 판명되었고(Fig. 4B), $\mathrm{BRAF}$ 는 음성이었으며, thyroglobulin 등의 추가 검사는 시 행하지 않았다. 좌측 갑상선에서는 $0.1 \times 0.1 \mathrm{~cm}$ 의 미세유두상 암종(papillary microcarcinoma)이 발견되었으며(Fig. 4C), 피막 외 침범이나 림프절 전이는 관찰되지 않았다. 또한 수술 시 관찰되었던 전 기관벽의 결손 부위는 육아종성 세포 증식 을 동반하는 만성 활동성 염증(chronic active inflammation with granulation tissue proliferation)으로 판명되었다(Fig. 4D).

수술 후 기관내삽관을 유지한 상태로 중환자실에서 경과 관찰하던 중, 수술 후 2 일째 경부 부종과 혈성 배액의 증가가 관찰되어 수술 후 출혈로 판단하고 전신 마취 하에 응급 수 술을 시행하였다. 이후 안정화되어 삽관 튜브 발관을 시도하 였으나, 발관 직후 호흡곤란 및 산소포화도 감소가 관찰되어 다시 기관내삽관을 시행하고, 기관절개술을 계획하였다. 기관 절개술을 위해 aspirin을 중단하고, intravenous heparin 투 여를 다시 시작하였다. 술 전 항혈전요법 3일째, 환자가 의식 저하 소견을 보여 시행한 뇌 전산화단층촬영에서 우측 전두엽 에 약 $7.1 \mathrm{~cm}$ 의 뇌내출혈(intracranial hemorrhage) 및 뇌실 내출혈(intraventricular hemorrhage)이 관찰되었으나, 적극 적 치료를 원하지 않아 요양시설로 전원되었다.

\section{고 찰}

갑상선 종양에 의한 상기도폐쇄의 증상은 드물게 나타나 는 증상으로 대부분 갑상선 암종에 의한 경우가 많다. ${ }^{2,5,6)}$ 갑
상선 종양에 의한 기관압박이나 기관내로 침범한 경우는 대 개 오랜 시간에 걸쳐 서서히 진행하므로 환자가 좁아진 기도 에 적응이 되어 실제로 호흡곤란을 호소하는 경우는 드물다. 하지만 종양내 출혈과 같이 급속히 크기가 증가하여 급성 상 기도폐쇄증상을 나타나는 경우도 있다.,4,7)

본 증례에서는 낭종내 출혈로 인한 종물의 크기가 급격히 증가하면서 급성 상기도폐쇄를 일으킨 것으로 추정하였다. 낭종내 출혈의 원인으로 환자가 1 개월 전 급성심근경색을 진 단받은 후 항혈전제를 복용한 것을 생각해 볼 수 있다. 전경 부종물이 단기간에 급속히 크기가 증가하는 경우에는 동맥 류나 동정맥루 등의 혈관성 종양 혹은 출혈 등을 감별해야 하 며 전이성 혹은 염증성 림프절 등도 감별해야 한다. ${ }^{8)}$ 갑상선 염이 심할 때도 종물의 크기가 급속히 증가하여 상기도폐쇄 를 유발할 수 있으며, 대부분 갑상선 기능이상에 의한 전신 증 상의 동반 유무로 감별할 수 있다.

진단에 경부 초음파 검사나 갑상선 스캔 검사가 반드시 필 요한 것은 아니며, 수술여부를 결정하는 데 가장 중요한 것은 호흡곤란 및 연하통 등의 임상양상이다. ${ }^{8)}$ 전산화단층촬영 등의 정밀검사 전에 기도폐쇄의 증상과 징후가 있다면 기관 삽관이나 기관절개를 통해 사전에 기도 확보를 하는 것이 우 선이다. 초기에는 경미한 기도폐쇄만을 보이는 경우에도 진 행하여 심각한 기도폐쇄가 발생할 수 있음을 알고 최선의 치 료방침을 결정해야 한다. 치료는 종물의 악성 가능성과 내과 적 치료에 효과가 없다는 점에서 수술이 최선의 치료방법이 라고 할 수 있다. ${ }^{9}$ 
국내외에서 양성 갑상선 종양이 급성 상기도폐쇄를 유발한 경우가 보고된 바 있으나 이는 대부분 종양이 기관연골을 압 박하여 발생한 것으로, 본 증례와 같이 만성적인 압박에 의 한 기관연골부의 괴사성 변화와 결손을 동반한 경우는 아직 보고된 바가 없다. 양성 갑상선 종양이 기관을 침범하고 괴사 성 변화를 일으킨 경우 악성화로의 변환 가능성을 의심해봐 야 한다고 알려져 있지만 우리 증례처럼 악성화 없이 만성 압 박에 의한 연골괴사를 보일 수도 있음을 염두에 두어야 할 것 으로 생각한다. 또한 육아종성 질환이 의심되는 경우에는 감 별을 위한 추가적인 검사가 필요하며, 본 증례에서는 육아종 성 질환이 의심되지 않아 영구 절편 병리조직학적 검사 이외 의 추가 검사는 시행하지 않았다.

오랜 시간 동안 서서히 크기가 증가한 갑상선 종양의 경우 술 전 방사선학적 검사를 통해 기관벽의 결손 유무에 대해 확 인하고, 적절한 수술 계획을 세우는 것이 중요하다. ${ }^{10)}$ 기관벽 의 결손이 발생한 경우 본 증례와 같이 흥쇄유돌근-골막 피 판을 이용하여 재건을 할 수 있으며, 이 방법은 비교적 간단 하게 일차적 재건이 가능하여, 기관내강으로 침범한 침습성 유두상 갑상선 암종의 보존적 절제 후 발생한 기관 결손 부위 에도 적용이 가능하다. 쇄골의 골막을 포함하기 때문에 혈관 신생(vascularization)이 유지되어 생육성, 유연성, 밀폐성을 갖춘 자가 이식편으로 장기간 추적 관찰을 통해 좋은 예후를 보고한 바 있다. ${ }^{11}$

진행성 갑상선암의 기관침범이 아니라도 갑상선 양성 종양 의 크기 증가로 인해 급성 상기도폐쇄 증상과 함께 기관연골 의 괴사가 일어날 수 있음을 염두에 두고 환자를 치료해야 할 것으로 생각한다.

\section{Acknowledgments}

This work was supported by research fund of Chungnam National University.

\section{REFERENCES}

1) Close LG, Costin BS, Kim EE. Acute symptoms of the aerodigestive tract caused by rapidly enlarging thyroid neoplasms. Otolaryngol Head Neck Surg 1983;91(4):441-5.

2) Banks CA, Ayers CM, Hornig JD, Lentsch EJ, Day TA, Nguyen SA, et al. Thyroid disease and compressive symptoms. Laryngoscope 2012;122(1):13-6.

3) Ioannidis O, Dalampini E, Chatzopoulos S, Kotronis A, Paraskevas G, Konstantara A, et al. Acute respiratory failure caused by neglected giant substernal nontoxic goiter. Arq Bras Endocrinol Metabol 2011;55(3):229-32.

4) Shin HA, Hong SP, Sohn IK, Kim CH. A case of huge substernal goiter causing acute respiratory failure. Korean J OtorhinolaryngolHead Neck Surg 2009;52(7):616-9.

5) Lawson W, Som HL, Biller HF. Papillary adenocarcinoma of the thyroid invading the upper air passages. Ann Otol Rhinol Laryngol 1977;86(6 Pt 1):751-5.

6) Park BJ, Kim BW, Lee JH, Lee JS. A case of acute airway obstruction due to intracystic hemorrhage of thyroid papillary cancer. Korean J Otolaryngol-Head Neck Surg 2004;47(7):675-8.

7) Koh YW, Lee SW, Kim HJ, Lee JY. Two cases of benign thyroid tumor inducing acute upper airway distress. Korean J Otolaryngol-Head Neck Surg 2006;49(7):751-4.

8) Shaha AR. Surgery for benign thyroid disease causing tracheoesophageal compression. Otolaryngol Clin North Am 1990;23(3):391-401.

9) Erbil Y, Bozbora A, Barbaros U, Ozarmağan S, Azezli A, Molvalilar S. Surgical management of substernal goiters: clinical experience of 170 cases. Surg Today 2004;34(9):732-6.

10) Cho JI, Kim YM, Choi WS, Lee MT, Lee SJ, Yang TY. Intraluminal invasion of upper aerodigestive tract by thyroid carcinoma. Korean J Otolaryngol-Head Neck Surg 2001;44(9):968-73.

11) Becker JH, Franz RC. The sternocleidomastoid myoperiosteal flap for the reconstruction of a tracheal defect. S Afr J Surg 2007;45(2): $56-7$. 